\title{
AGRICULTURE, TRADE REFORM AND POVERTY REDUCTION: IMPLICATIONS FOR SUB-SAHARAN AFRICA
}

\author{
by \\ Kym Anderson \\ CEPR, and School of Economics and \\ Centre for International Economic Studies \\ University of Adelaide \\ Adelaide SA 5005 Australia
}

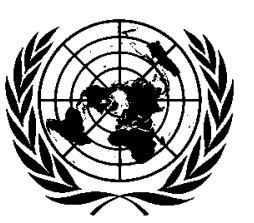

UNITED NATIONS

New York and Geneva, 2004 


\section{NOTE}

The purpose of this series of studies is to analyze policy issues and to stimulate discussions in the area of international trade and development. The series includes studies by UNCTAD staff, as well as by distinguished researchers from academia. In keeping with the objective of the series, authors are encouraged to express their own views, which do not necessarily reflect the views of the United Nations.

The designations employed and the presentation of the material do not imply the expression of any opinion whatsoever on the part of the United Nations Secretariat concerning the legal status of any country, territory, city or area, or of its authorities, or concerning the delimitation of its frontiers or boundaries.

Material in this publication may be freely quoted or reprinted, but acknowledgement is requested, together with a reference to the document number. It would be appreciated if a copy of the publication containing the quotation or reprint were sent to the UNCTAD secretariat:

\section{Chief}

Trade Analysis Branch

Division on International Trade in Goods and Services, and Commodities United Nations Conference on Trade and Development

Palais des Nations

CH-1211 Geneva

Series Editor:

Sam Laird

Officer-in-Charge, Trade Analysis Branch

DITC/UNCTAD

UNCTAD/ITCD/TAB/24

\begin{tabular}{|c|}
\hline UNITED NATIONS PUBLICATION \\
\hline Sales No. E.04.II.D.5 \\
\hline ISBN 92-1-115612-6 \\
\hline ISSN 1607-8291 \\
\hline
\end{tabular}

(C) Copyright United Nations 2004

All rights reserved 


\begin{abstract}
The current WTO negotiations have a strong focus on development, but a number of developing countries are uncertain as to how to approach these negotiations. Trade liberalization tends to boost economic growth and contribute to the reduction of poverty in the longer term but, it may also impose important short-term adjustment costs. This study explores the poverty implications of the current post-Doha multilateral trade reform agenda of the WTO for developing countries, so those benefits can be weighed against perceived adjustment costs. It addresses the effects of trade reform on poverty at three levels: first on developing countries as a group; then on different types of developing countries; and finally on different types of households within developing countries. The modelling results point to both opportunities and challenges provided by the WTO negotiations for developing countries seeking to trade their way out of poverty. While important gains are to be made from liberalization in the OECD countries, the study also highlights gains to be made from policy changes in the developing countries that would help to reduce the anti-agriculture, anti-export and anti-poor bias of current policies. The paper addresses such questions as whether food-importing countries would suffer from higher food prices in international markets, and what impact reform could have on food security and poverty alleviation. It concludes with lessons of relevance for the domestic and trade policies of developing countries.
\end{abstract}




\section{ACKNOWLEDGEMENTS}

Paper prepared for the Trade Analysis Branch of UNCTAD in Geneva. Thanks are due to UNCTAD, the World Bank and the University of Adelaide for financial support. 


\section{CONTENTS}

Introduction 1

I. Potential gains for developing countries

from the WTO's Doha development agenda.

II. Does it matter that global trade reform erodes tariff preferences?

III. Would food-importing countries lose from higher international food prices?

IV. Would poverty and food insecurity increase in Africa

because of higher international food prices?

V. The risk of re-instrumentation of agricultural protection

VI. Conclusions and policy implications .

References 


\section{Tables}

1. Average tariff equivalents of import market access barriers to goods trade, by source and destination region, 1995 .

2. Sectoral and regional contributions to economic welfare gains from completely removing trade barriers globally, post-Uruguay Round, 2005

3. Disaggregation of sectoral and regional contributions to economic welfare gains from completely removing trade barriers globally, post-Uruguay Round, 2005 ...... 6

4. Percentage difference in sectoral output when all merchandise trade distortions remaining post-Uruguay Round are removed, 2005. .8

5. Changes in sectoral trade balances when all merchandise trade distortions remaining post-Uruguay Round are removed, 2005 9 


\section{INTRODUCTION}

The WTO Ministerial Declaration at Doha in November 2001 places considerable emphasis on development (WTO, 2001b), although the outcome is not guaranteed. Many developing countries - particularly in Africa are sceptical that they will receive sufficient gains from that MTN to warrant the inevitable costs of negotiations and adjustments. These countries and some donors also still need to be convinced that such trade reform will alleviate rather than add to poverty and food insecurity in developing countries. Some are concerned about the loss of trade preferences as developed countries' MFN tariffs are reduced. Net food-importing countries are especially worried that they will be made worse off by having to pay a higher food import bill following agricultural trade reform.

Trade policy does not deal with income distribution issues, because in virtually all countries they can be handled more efficiently by more direct policy measures (Corden, 1997, Ch. 4). Nonetheless, it is important to be aware of the distributional consequences of trade (and other) policy changes and to check that measures are in place or, are introduced to deal effectively with any vulnerable groups who may be made worse off by those trade reforms abroad and/or at home.

It is estimated that between 350 million and 1.2 billion people live on less than US $\$ 1$ a day, most of whom are in rural Sub-Saharan Africa and South Asia (Sala-i-Martin, 2002; Collier and Dollar, 2002; etc). This study looks at the likely effects of the current WTO negotiations on poverty alleviation with a particular focus on agriculture and rural households in developing countries, especially those in Africa. The reason for the rural focus is not just because that is where most of the world's poor live and work, but also because agricultural markets are the most distorted in the world and hence any across-the-board cut in trade distortions would bring down the relative price of agricultural products in international markets.

There is a large body of empirical evidence showing that trade liberalization easing tariffs and other import restrictions as well as reducing or eliminating domestic supports and export subsidies - tends to boost economic growth, at least in the longer term, and this has helped to reduce the number of persons living in absolute poverty (Dollar and Kraay, 2000). In the longer term, and in the absence of externalities, own-country liberalization tends to increase aggregate welfare through improvements in resource allocation and employment generation but, there will always be some who lose in the absence of compensation. However, in the short-term structural adjustment costs and the immediate impact on the poor may be negative, particularly in developing countries that do not have the resources, institutions or infrastructure to facilitate the changes nor the social safety nets to cushion the negative effects. Changes in trade policies in other countries also have an impact through altering a country's terms of trade, which again can generate winners and losers within each developing country. If the combination of the effects of reforms at home and overseas is propoor, it will reinforce any positive growth effects of trade reform on the poor; but for countries where those changes are not likely to be pro-poor, governments may need to amend domestic policies or boost public investments to prevent a deterioration in the 
welfare of vulnerable groups. To achieve this, the developing countries are likely to need some leeway and external support through the provision of resources to build "soft" and "hard" infrastructure.

The many African countries that are heavily dependent on exports of farm commodities can anticipate being better off following WTO-induced trade reform, particularly by the developed countries, which use an array of instruments to support their farm sectors and limit access and entry to their markets. The elimination of these trade distortions would level the playing field, and make it more feasible for African countries to contemplate undertaking their own reforms that would otherwise expose their fragile sectors to unfair competition. Those African countries whose food imports represent a large part of their foreign payments could face a higher food import bill but, if their farmers can respond to expected increases in international prices - however modest - as export subsidies are reduced by the developed countries, this could have positive effects on food security and poverty alleviation. Therefore, all African countries need to play an active role in the WTO negotiations to ensure that their particular interests are taken into account.

The quantitative analysis in this study shows that about half of the potential global economic welfare gains from trade reform would come from changes in the policies of the OECD countries in the agriculture and processed food sectors. The present analysis also confirms earlier analyses (e.g., Krueger, Schiff and Valdes, 1988) showing that some developing countries have an anti-agriculture, anti-poor bias in their own policies and so are not making the best use of their own resources - although the extent of that has been reducing over the past decade or two (see Jensen, Robinson and Tarp, 2002).

These welfare results are driven by improvements in the terms of trade (e.g. export prices rising more than import prices) and the efficiency effects of improvements in the allocation of resources between different activities. This study looks at changes in prices, outputs and trade balances by sector, which can expose potential adjustment problems and policy dilemmas for developing countries. However, it should be kept in mind from the outset that the results are based on a comparative static analysis, comparing a preand post-liberalization situation, without taking account of transition periods or adjustment costs such as the movement of resources from highly-protected industrial sectors in developing countries. ${ }^{1}$ The results are also limited in that SPS and TBT barriers and other market entry restraints that developing countries face in their major markets are not modelled, and perfect competition is assumed.

The effects of trade reform on poverty are addressed at three levels: first focusing on developing countries as a group; then on different types of developing countries and finally, on different types of households within developing countries.

${ }^{1}$ If current interventions in favour of the industrial sector have social benefits, they can almost always be achieved by more efficient instruments than trade policies. 


\section{POTENTIAL GAINS FOR DEVELOPING COUNTRIES FROM THE WTO's DOHA DEVELOPMENT AGENDA}

Tariffs facing poor-country exports to other markets are high. At the end of the Uruguay Round negotiations, the tariff equivalent of import market access barriers to goods trade were on average quite modest, and even low for minerals and energy raw materials, but they were high for a few manufactures, especially textiles and clothing, and even higher for agricultural goods entering both rich and poor countries (Table 1). Since developing countries' interests in market access opportunities abroad are primarily in either farm products and/or light manufactures such as textiles and clothing - goods that are the most protected in world trade (see also WTO, 2001a) - they would appear to have a great deal to gain potentially from the new WTO negotiations.

Of all the economic gains to be had in 2005 from removing the barriers to trade in goods that will still be in place after all Uruguay Round commitments are implemented, almost half ( 48 per cent) would come from changes in the agricultural and processed food policies in OECD countries (Table 2) - even though such products in those countries contribute only 4 per cent of global GDP and less than one-tenth of world trade. ${ }^{2}$ However, a further one-sixth of the welfare gains would come from making improvements in the farm and food policies of developing countries.

Table 1

Average tariff equivalents of import market access barriers to goods trade, by source and destination region, 1995

(per cent)

\begin{tabular}{cccc}
\hline & \multicolumn{2}{c}{ Importing region: } & \\
\cline { 2 - 3 } Exporting region: & High Income & Low Income & World \\
\hline Agriculture & & & \\
High Income & 16 & 22 & 18 \\
Low Income & 15 & 18 & 16 \\
World & 16 & 20 & 17 \\
Manufactures & & 11 & \\
High Income & 1 & 13 & 4 \\
Low Income & 3 & 12 & 5 \\
World & 2 & & \\
Minerals/energy & & 1.3 & 0.4 \\
High Income & 0.1 & 5.2 & 2.4 \\
Low Income & 0.4 & 3.0 & 1.1 \\
World & $\mathbf{0 . 2}$ & & \\
\hline
\end{tabular}

Source: Hertel et al. (2004).

${ }^{2}$ Estimates based on analysis using the GTAP (Global Trade Analysis Project), which is a global applied general equilibrium model based in Purdue University (Hertel, 1997). The GTAP model is a standard, multi-region model that is currently in use by several hundred researchers in scores of countries on five continents. The Version 4 database builds on contributions from many of these individuals, as well as the national and international agencies in the GTAP Consortium. 
Table 2

Sectoral and regional contributions to economic welfare gains $s^{a}$

from completely removing trade barriers globally, post-Uruguay Round, 2005

(a) in 1995 US\$ billions

\begin{tabular}{cccccc}
\hline $\begin{array}{c}\text { Liberalizing Region } \\
\text { Benefitting region }\end{array}$ : & $\begin{array}{c}\text { Agriculture } \\
\text { and Food }\end{array}$ & $\begin{array}{c}\text { Other } \\
\text { Primary }\end{array}$ & $\begin{array}{c}\text { Textiles \& } \\
\text { Clothing }\end{array}$ & $\begin{array}{c}\text { Other } \\
\text { Manufactures }\end{array}$ & Total \\
\hline High Income & & & & & \\
High Income & 110.5 & -0.0 & -5.7 & -8.1 & 96.6 \\
Low Income & 11.6 & 0.1 & 9.0 & 22.3 & 43.1 \\
$\quad$ Total & 122.1 & 0.0 & 3.3 & 14.2 & 139.7 \\
Low Income & & & & & \\
High Income & 11.2 & 0.2 & 10.5 & 27.7 & 49.6 \\
$\quad$ Low Income & 31.4 & 2.5 & 3.6 & 27.6 & 65.1 \\
$\quad$ Total & 42.6 & 2.7 & 14.1 & 55.3 & 114.7 \\
All Countries & & & & & \\
High Income & 121.7 & 0.1 & 4.8 & 19.6 & 146.2 \\
$\quad$ Low Income & 43.0 & 2.7 & 12.6 & 49.9 & 108.1 \\
Total & 164.7 & 2.8 & 17.4 & $\mathbf{6 9 . 5}$ & 254.3 \\
\hline
\end{tabular}

(b) in per cent of total global gains

\begin{tabular}{cccccc}
\hline $\begin{array}{c}\text { Liberalizing Region: } \\
\text { Benefitting region: }\end{array}$ & $\begin{array}{c}\text { Agriculture } \\
\text { and Food }\end{array}$ & $\begin{array}{c}\text { Other } \\
\text { Primary }\end{array}$ & $\begin{array}{c}\text { Textiles \& } \\
\text { Clothing }\end{array}$ & $\begin{array}{c}\text { Other } \\
\text { Manufactures }\end{array}$ & Total \\
\hline High Income & & & & & \\
High Income & 43.4 & 0.0 & -2.3 & -3.2 & 38.0 \\
Low Income & 4.6 & 0.1 & 3.5 & 8.8 & 16.9 \\
$\quad \begin{array}{c}\text { Total } \\
\text { Low Income }\end{array}$ & 48.0 & $\mathbf{0 . 0}$ & $\mathbf{1 . 3}$ & 5.6 & 54.9 \\
$\quad$ High Income & 4.4 & 0.1 & 4.1 & 10.9 & 19.5 \\
Low Income & 12.3 & 1.0 & 1.4 & 10.9 & 25.6 \\
$\quad$ Total & 16.7 & 1.1 & 5.5 & 21.7 & 45.1 \\
All Countries & & & & & \\
High Income & 47.9 & 0.1 & 1.9 & 7.7 & 57.5 \\
Low Income & 16.9 & 1.0 & 4.9 & 19.6 & 42.5 \\
Total & $\mathbf{6 4 . 8}$ & $\mathbf{1 . 1}$ & $\mathbf{6 . 8}$ & $\mathbf{2 7 . 3}$ & $\mathbf{1 0 0 . 0}$ \\
\hline
\end{tabular}

${ }^{a}$ No account is taken in these calculations of the welfare effects of environmental changes associated with trade liberalization, which could be positive or negative depending in part on how environmental policies are adjusted following trade reforms.

${ }^{\mathrm{b}}$ High and low income here are short-hand for developed and developing countries.

Source: Anderson et al. (2001).

Textiles and clothing reforms would be the next biggest contributor, although they appear small by comparison with agricultural reform: their potential global welfare contribution is only one-ninth that of agriculture's ( 7 per cent compared with 65 per cent). This big difference reflects two facts: one is that projected distortions to prices for agriculture are more than twice those for textiles and clothing in 2005; the other is that textiles and clothing contribute only 1.5 per cent to the value of world production and 5 per cent to the value of world trade, half or less the shares for farm products. 
The results in the textiles and clothing sectors, reported in Table 2, assume that OECD countries fully implement the spirit of the ATC by the end of 2004, that is, all remaining import quotas and 'voluntary' export restraints are removed and are not replaced with similarly protective instruments such as anti-dumping or safeguard measures. It is also assumed in the modelling exercise that China and Taiwan Province of China, which acceded to the WTO at Doha, would enjoy the same access to OECD markets under the Uruguay Round Agreement on Textiles and Clothing (ATC) as other developing countries.

These results underline the major stake that developing countries have in the continuation of comprehensive farm policy reform covering tariffs as well as domestic supports and export subsidies that are largely provided by the developed countries. They suggest farm and food policies contribute 40 per cent (43.0/108.1) of the cost to developing economies of global trade distortions in goods. Textile and clothing policies of the developed countries also harm them greatly, but barely one-third as much as farm policies. ${ }^{3}$ They also indicate the relative importance of the reforms in the developed and developing countries. Table 2 shows that almost half of the gains to low-income countries derives from policy changes in the rich countries $(43.1 / 108.1)$ and one quarter of that increase derives from policy changes in the agriculture and food sector. Changes in policies in low-income countries also make a substantial contribution to other low-income countries' economic welfare (65.1/ 108.1), and that almost half of that gain (31.4/ 65.1) comes from policy changes in the agriculture and food sectors. This reflects the importance not only of own-country reform but also of expanding South-South trade: between the 1980s and 2001, the share of developing countries' agricultural exports going to other developing countries rose from 28 per cent to 37 per cent (World Bank, 2003, Table 3.6).

These results also highlight that in the absence of externalities that are not identified here, the developing countries could also gain from eliminating biases against their own export industries including the agricultural sector where the poorest segment of society works. Full liberalization of rich-country farm policies would cause real international food prices to rise by 5 per cent on average, ceteris paribus (not covered in reported tables). For the subset of low-income countries that would remain net food-importing economies after reform and thereby suffer a deterioration in their terms of trade, the extent of the rise in their food import prices would therefore be very small since any Doha outcome is likely to involve only a partial reform and one that will be phased in over several years.

The results for developing countries in Table 2 are disaggregated in Table 3 to show the effects on various regions. Under the assumptions of the model, virtually all regions are net gainers from complete abolition of all forms of trade intervention. (This refers to tariffs, applied across the agricultural and industrial sectors by all groups of countries, restraints on textiles and clothing applied by the industrial countries and, domestic supports and export subsidies applied in the agricultural sectors by industrial countries). ${ }^{4}$ While some of them suffer a terms-of-trade deterioration, that cost is more than offset by the improved efficiency of domestic resource use following

${ }^{3}$ It should be recognized that these results ignore the effect of tariff preference erosion. In so far as developing countries receive and utilize such preferences at present in OECD markets, the above results slightly overstate the potential gains from their reforms. This point is taken up below. intervention.

${ }^{4}$ See, for example, UNCTAD, "Back to Basics", Geneva, 2003, for a discussion on patterns of trade 


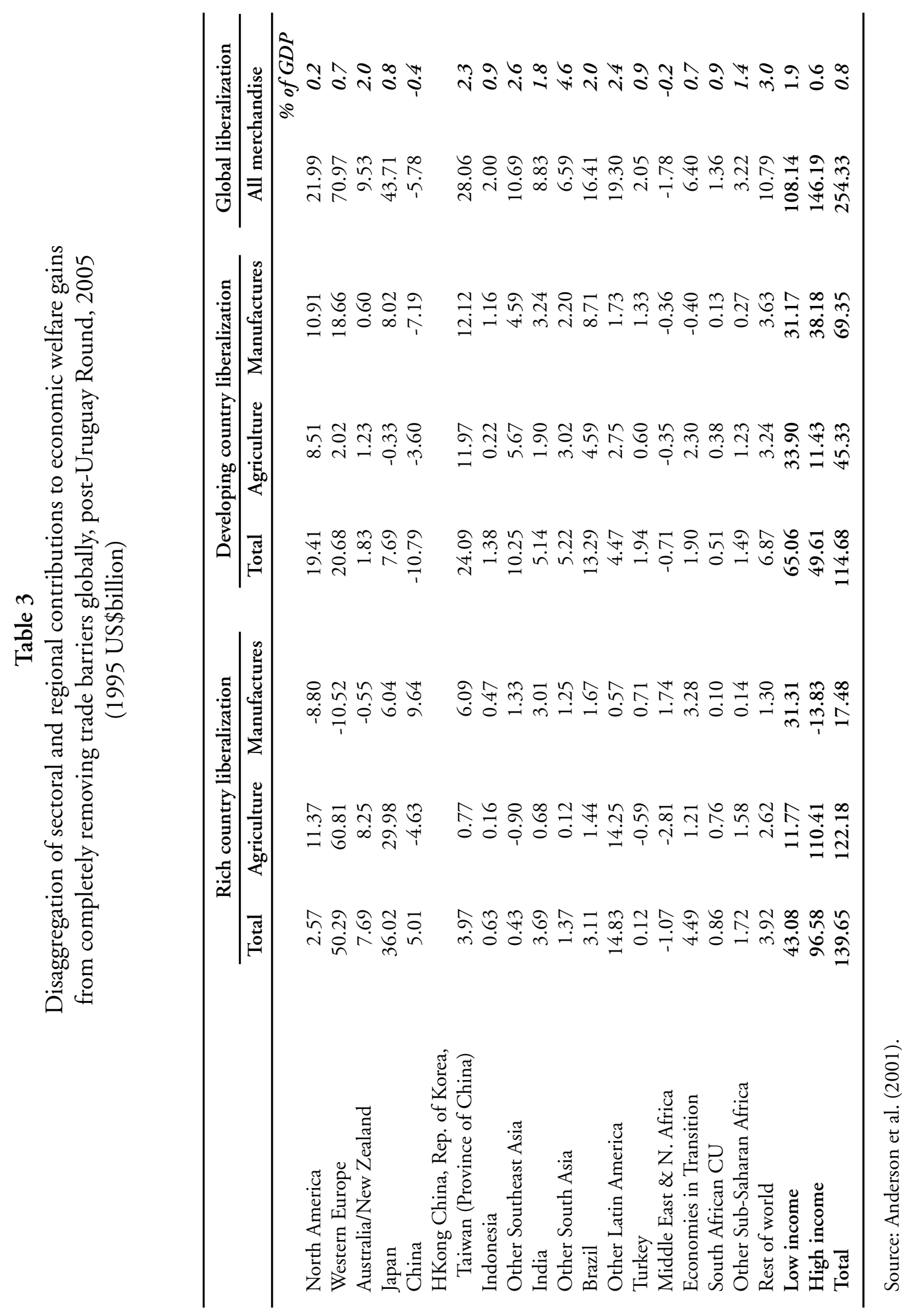


reform. In $1995^{5}$ U.S. dollar terms, the gains from global liberalization would be almost as great for South-East Asia as for South Asia, while less than half as large for the much smaller economic region of Sub-Saharan Africa. However, being more agrarian, SubSaharan Africa would gain proportionately more than Asia from agricultural trade reform by either rich or poor countries.

The final two columns of Table 3 reveal that, even though developing countries would gain slightly less than rich countries in aggregate dollar terms from the global elimination of all forms of trade intervention in goods, ${ }^{6}$ they gain as much as 1.9 per cent of GDP, more than three times the percentage for rich countries. For Sub-Saharan Africa (other than SACU) as a group, the gain would be 1.4 per cent of its GDP.

In the analysis, developing countries as a group would make further gains as a result of the restructuring of their policies. To illustrate the point, Anderson and Yao (2003) examined the effects on low-income countries in Sub-Saharan Africa and South Asia, first without, and then with that group participating in the removal of trade interventions. If all regions other than South Asia and Sub-Saharan Africa were to eliminate all forms of intervention in trade that remain after the end of 2004 (when all Uruguay Round commitments are to have been implemented), the world economy would structurally adjust to allow each region to exploit even more its comparative advantages. In effect, as a result of policy changes in other countries, there would necessarily be changes in the trade and industrial structures in Sub-Saharan Africa and South Asia even if they chose not to join in such policy changes (Table 4(a)). In particular, there would be an expansion in agricultural production at the expense of labour-intensive manufacturing in those low-income countries. In some instances, individual non-agricultural sectors would face a contraction in absolute terms, while others would expand but to a lesser extent than agriculture. Output of grains other than wheat, and of livestock, would expand in Sub-Saharan Africa.

There are important gains in agricultural exports as a result of the simulated elimination of all forms of trade intervention, and a decline in net food imports. However, there are important variations as between industries (Table 5). ${ }^{7}$ There are gains in most agricultural sectors (except "other crops" in Sub-Saharan Africa when that region and South Asia are excluded from the reforms). On the positive side, there are also marked net trade gains in the energy and minerals sectors. However, "other" manufactures faces an important trade loss, especially if developing countries join in the elimination of trade measures (mainly industrial tariffs in this case), The counter to this would be corresponding net gains for developed countries but, other developing regions especially in South-East Asia may also be winners.

\section{${ }^{5} 1995$ is the base year provided by the GTAP 4 database.}

${ }^{6}$ There are a wide variety of measures used for trade intervention. The UNCTAD TRAINS database covers over 100 measures affecting imports. However, OECD lists more than 150 measures in agriculture alone. See Laird (1997) for a discussion. The GTAP database uses the ad valorem equivalent of various forms of trade intervention. See Hertel (1997) for the measures included in the GTAP database.

7 Anderson and Yao (2003) suggest Sub-Saharan Africa's economic welfare gain is twice as great from participating in than from standing aside from trade liberalization. However, most of that greater gain goes to the South African Customs Union. The reason that Other Sub-Saharan Africa as an aggregate does not gain even more in the simulations is that the very considerable gains from more efficient resource use would be offset by an adverse change in the region's terms of trade when all of those countries expand their primary product exports simultaneously. 
Table 4

Percentage difference in sectoral output when all merchandise trade distortions remaining post-Uruguay Round are removed, 2005

(a) Reform in all regions except Sub-Saharan Africa and South Asia

\begin{tabular}{lcccc}
\hline & South & $\begin{array}{c}\text { Other } \\
\text { Sub-Sahara }\end{array}$ & & $\begin{array}{c}\text { Other } \\
\text { South } \\
\end{array}$ \\
& Africa & Africa & India & Asia \\
\hline Rice & 6 & 1 & 12 & 9 \\
Wheat & 18 & 2 & 6 & 6 \\
Other cereal, Grain & 114 & 85 & 1 & 1 \\
Veg, Fruit, Nuts & 1 & 0 & 1 & 1 \\
Oilseeds & 2 & 3 & -1 & 2 \\
Other crops & 43 & -8 & -2 & 1 \\
Plant fibre & -12 & 11 & -2 & 0 \\
Livestocks & 28 & 15 & 0 & 1 \\
Other food products & 28 & 2 & -2 & 29 \\
Meat, Dairy products & 38 & 14 & 1 & 3 \\
Forestry, Fish & 2 & 0 & 0 & 1 \\
Energy, Minerals & -2 & 0 & 1 & 2 \\
Veg. oils, Fats & 0 & 0 & -4 & -5 \\
Textile, Wap & -8 & -2 & -10 & -16 \\
Other Manufactures & -7 & 0 & 3 & 11 \\
Services & 0 & 0 & 0 & 0 \\
\hline
\end{tabular}

(b) Reform in all regions including Sub-Saharan Africa and South Asia

\begin{tabular}{lcccc} 
& South & Other & & Other \\
& Africa & Sub-Sahara & & South \\
& 4 & -1 & 19 & Asia \\
\hline Rice & -3 & -6 & 15 & 78 \\
Wheat & 171 & 90 & 1 & 2 \\
Other cereal, Grain & 1 & 9 & 0 & -3 \\
Veg, Fruit, Nuts & -5 & -1 & 0 & 7 \\
Oilseeds & 61 & 9 & -2 & -4 \\
Other crops & -10 & -1 & -2 & -1 \\
Plant fibre & -6 & 54 & 0 & 6 \\
Livestock & 22 & 3 & 1 & 38 \\
Other food products & -6 & 0 & 2 & 8 \\
Meat, Dairy products & 7 & 4 & 0 & 3 \\
Forestry, Fish & 29 & 7 & 6 & 3 \\
Energy, Minerals & 0 & 2 & -15 & -17 \\
Veg. oils, Fats & 1 & -13 & 5 & 29 \\
Textile, Wap & -8 & -5 & 19 & 60 \\
Other Manufactures & 1 & 0 & 2 & 4 \\
Services & & & & 7 \\
\hline
\end{tabular}

Source: Anderson and Yao (2003). 
Table 5

Changes in sectoral trade balances when all merchandise trade distortions remaining post-Uruguay Round are removed, 2005

(a) Reform in all regions except Sub-Saharan Africa and South Asia

\begin{tabular}{lrrrr}
\hline & $\begin{array}{c}\text { Other } \\
\text { South }\end{array}$ & $\begin{array}{c}\text { Oub-Sahara } \\
\text { Africa }\end{array}$ & India & $\begin{array}{r}\text { Other } \\
\text { South } \\
\text { Asia }\end{array}$ \\
\hline Rice & -54 & 28 & 1,897 & 397 \\
Wheat & -50 & 44 & 671 & 48 \\
Other cereal, Grain & 1,016 & 1,815 & 50 & 1 \\
Veg, Fruit, Nuts & -114 & -8 & 67 & -17 \\
Oilseeds & -79 & 48 & 119 & 39 \\
Other crops & 2,427 & $-2,068$ & 28 & -108 \\
Plant fibre & -106 & 589 & 30 & -70 \\
Livestock & 21 & 365 & 6 & 4 \\
Other food Products & 5,062 & 339 & -494 & 3,232 \\
Meat, Dairy products & 2,954 & 569 & 153 & 130 \\
Forestry, Fish & -4 & -54 & 0 & -25 \\
Energy, Minerals & -436 & -198 & 185 & -297 \\
Veg. oils, Fats & -145 & -22 & -186 & -70 \\
Textile, wap & -498 & -143 & $-7,159$ & $-6,315$ \\
Other Manufactures & $-8,066$ & -469 & 4,552 & 3,484 \\
Services & $-1,927$ & -836 & 80 & -433 \\
\hline
\end{tabular}

(b) Reform in all regions including Sub-Saharan Africa and South Asia

\begin{tabular}{lrrrr}
\hline & $\begin{array}{c}\text { South } \\
\text { Africa }\end{array}$ & $\begin{array}{c}\text { Other } \\
\text { Sub-Sahara } \\
\text { Africa }\end{array}$ & India & $\begin{array}{r}\text { Other } \\
\text { South } \\
\text { Asia }\end{array}$ \\
\hline Rice & -82 & -54 & 2,565 & 689 \\
Wheat & -152 & -252 & 1,736 & 163 \\
Other cereal, Grain & 1,681 & 1,911 & 67 & 0 \\
Veg, Fruit, Nuts & -66 & 881 & -118 & -590 \\
Oilseeds & -62 & 68 & 224 & -175 \\
Other crops & 3,609 & 1,704 & -647 & $-2,001$ \\
Plant fibre & -73 & 158 & -244 & -782 \\
Livestock & 73 & 1,146 & -3 & 7 \\
Other food products & 4,976 & 230 & 195 & 3,530 \\
Meat, Dairy products & -480 & -239 & 458 & 36 \\
Forestry, Fish & 29 & 270 & -234 & -148 \\
Energy, Minerals & 6,760 & 4,442 & -410 & $-3,381$ \\
Veg. oils, Fats & -125 & -46 & $-1,292$ & -585 \\
Textile, Wap & -605 & $-1,490$ & 629 & 3,706 \\
Other Manufactures & $-14,086$ & $-8,054$ & $-5,068$ & 1,698 \\
Services & $-1,398$ & -676 & 2,142 & $-2,168$ \\
\hline
\end{tabular}

Source: Anderson and Yao (2003). 
These net changes in output and trade underline the point that while there may be net economic welfare gains associated with a country's own liberalization, there can be important structural changes which could have serious negative effects in specific sectors (not allowing even for externalities). This apparent policy dilemma arises because the estimated gains in economic welfare are based on comparative static analysis, looking at the preand post-liberalization situations without specifying the transitional period or taking any account of adjustment costs. If developing countries wish to pursue the longer term welfare goals that are so important for the rural poor without appropriate supporting policies, they could face negative shocks in their urban industrial sectors, leading to a process of deindustrialization and a possible need for social safety nets, re-training and adjustment programmes to help any displaced urban workers.

Does this mean that Sub-Saharan Africa should be indifferent to or should refuse to participate in the WTO negotiations? The answer is certainly not. On the contrary, they would be worse off if their governments did not participate actively in the WTO process. First, these countries would forego the opportunity to safeguard their own trade interests and to seek greater access for their exports to other markets. Second, they would forego the opportunity to obtain economic efficiency gains from reducing the policy biases against their own rural sectors, while still suffering the terms of trade loss from others' reforms (or lack thereof), since any one of those countries is too small for its own policy choice to alter the terms of trade significantly. ${ }^{8}$ The fact that other countries are also undertaking reforms sometimes makes it politically easier for governments to introduce similar changes at home. Thirdly, developing countries that face important structural adjustments, tariff revenue and preference losses would be able to argue a case for support for institution-building and the implementation of programmes to facilitate adjustment and to provide social safety nets and compensation from the developed countries that win from the negotiations. It may also be helpful in persuading bilateral donors and the IFIs, under the coherence mandate, to help Sub-Saharan African countries overcome serious supply constraints in the real economy, for example in infrastructure projects and overcoming technical barriers to trade.

The analysis suggests that in order for Sub-Saharan Africa to benefit from the WTO negotiations, certain preconditions need to be met. These include: flexibility and an appropriate pace and sequencing of their own reforms; a levelling of the playing field through the reduction and elimination of tradedistorting subsidies and support by OECD countries and, the lowering of market access and entry barriers; adequate resources from the IFIs and developed countries to help developing countries adjust to the loss of trade preferences and tariff revenue losses ${ }^{9}$ and, assistance to overcome supply constraints.

\section{Further qualifications to the global modelling results}

There are three other important sources of gains from trade reform that are not reflected in the above results, namely, gains from reform to trade in services, gains from increasing

${ }^{8}$ For empirical support for this proposition, see for example Anderson and Strutt (1999) with respect to Indonesia. The point is made strongly also in the volume on the Uruguay Round edited by Martin and Winters (1996).

9 The computations suggest that the welfare gains by the OECD countries should make some compensation for preference and revenue losses easily affordable. The EU's internal compensation schemes for its own farmers could provide one such model. 
competition, economies of scale, and dynamic gains.

The nature of service sector policies makes estimating their effects much more difficult than is the case for barriers to trade in goods. At present, economists are trying to identify and quantify the effects of interventions in the services sector and, the preliminary results of such work suggest that there are very substantial gains to be made from the liberalization (but not deregulation) of this sector. ${ }^{10}$ Yet the gains to developing countries from liberalization in the services sectors are potentially very large. These gains include those that derive from the improved access of developing countries to labour markets in the developed countries ("Mode 4" of the General Agreement on Trade in Services, GATS), as shown by Winters, Walmsley, Wang and Grynberg (2003) in their study for the Commonwealth Secretariat, and a number of UNCTAD studies also indicate considerable potential for gains in tourism, cultural services and other areas. In addition, there are important gains to be made in those developing countries where services have yet to be opened up to a greater degree of competition. Those gains would come not just directly to consumers but also to producers who purchase services as intermediate inputs into their goods production. Farmers in particular would benefit from services reform because they depend heavily on such things as transport services to get their produce to domestic and overseas markets.

Other attempts to measure distortions to services trade together with mark-ups by imperfectly competitive firms also are beginning to bear fruit. A study by Francois (2001) includes one set of estimates of the tariff equivalent of those distortions in a version of the GTAP model that also incorporates imperfect competition and scale economies.
Specifically, that study assumes monopolistic competition exists in the non-primary sectors involving economies of scale that are internal to each firm. These modifications amplify the estimated gains from trade considerably. For example, that study finds that if trade interventions in both goods and services were to be cut in half, the global gains would be US $\$ 385$ billion, of which 51 per cent would be due to services reform. The 49 per cent due to halving tariffs on goods trade (US $\$ 192$ billion) in the Francois study compares with the above estimate (where no imperfect competition is assumed) of around US $\$ 250$ billion from totally removing all tariffs on merchandise trade. The key point to draw from this comparison is that the gains from trade reported above should be interpreted as lowerbound estimates for at least two reasons: because they apply only to goods trade, leaving aside the important distortions prevalent in services markets; and because they are based on the assumption that there are no economies of scale and that perfect competition prevails in all sectors.

Both aspects of this point are especially important for Sub-Saharan Africa, especially as it applies to ocean shipping (Francois, 2001, Table C.2). Two-thirds of Sub-Saharan African exports are primary products, most of which are shipped in bulky unprocessed or semiprocessed form. The region's export earnings are thus affected significantly by the cost of ocean shipping services. That service sector is characterized by a high degree of oligopolistic activity on the part of ship owners, virtually all of whom are developed country firms. While that service sector remains restrictive, the benefits of freer trade will be go in part to the cartel of ship owners who can charge a higher mark-up above their marginal costs as import tariffs on goods are lowered. To illustrate this, a recent empirical study was undertaken by Francois and Wooten (2001).

${ }^{10}$ See for example, Findlay and Warren (2000), the McGuire study for UNCTAD, Winters, Walmsley, Wand and Grynberg (2003), Brown, Deardorff and Stern (2001), and Francois and Wooten (2001). 
They estimate that depending on the degree of collusion, shippers could absorb for themselves, in the form of higher mark-ups, up to half the gains that exporters would otherwise enjoy from goods trade liberalization if shipping were a competitive service activity. The conclusion to draw from the Francois/ Wooten study is that if the developing countries are to realize the full gains from trade liberalization in the area of goods and especially of bulk commodities, then it is necessary to take supporting actions in the area of services, through the liberalization of trade in maritime services and, through competition policy measures at the international level to ensure that the benefits are fully passed on to users of those services.

None of the studies reported above draw on a truly dynamic economic model. They measure well the effects of producers reallocating their resources and consumers adjusting their purchases when relative product prices change with trade reform but, they do not measure the impact of such reform on investment behaviour. However, when markets are freed, investors divert their funds towards expanding the now more-profitable activities and away from the now less-profitable ones. They are also willing to invest more in aggregate because of the reduced uncertainty associated with binding the reforms in WTO schedules. That boost to investment applies even more following the reductions in barriers to foreign investment and hence international technology transfers of the past two decades. Thus economic growth is boosted by that diversion and expansion of investment funds, over and above the boost in output from reallocating existing resource endowments.

This additional effect is omitted from most empirical modelling efforts for two reasons: partly because it takes much longer for analysts to build and to run dynamic models than comparative static ones and, partly because the extent to which investors respond to changing incentives is less well understood and hence cannot be included with as much certainty as the other behavioural characteristics that are common to both comparative static and dynamic models. It is instructive to note the results of a recent study that examined the range of outcomes generated as the responsiveness of productivity to openness is varied.

The World Bank (2002, Ch. 6) conducted a study very similar to the one reported above, and obtained very similar results when its version of the GTAP model was in comparative static mode (a global welfare gain from complete liberalization of merchandise trade of US $\$ 355$ billion per year by 2015 , compared with the present study's estimate of US $\$ 254$ billion as early as 2005 when the world economy would be somewhat smaller, and with agricultural policies still responsible for about two-thirds of that gain). When their same model was switched into dynamic mode however, that global gain increased two to three-fold over reasonable ranges of productivity responsiveness parameters. This adds further weight to the claim that the earlier welfare results should be considered as very much lower-bound estimates of the gains from trade liberalization.

Developing countries in Sub-Saharan Africa have much to gain economically from taking a pro-active stance in the WTO negotiations. They have much to gain from enhanced access to premium markets in developed countries as well as access to other developing countries. In the longer term, their capacity to take advantage of these opportunities can also be enhanced by policies to improve their competitiveness, including supply-side measures, competition policies and the progressive elimination of distortions in sectoral policies in order to increase the proagriculture, pro-export and pro-poor thrust of their policies. 


\section{DOES IT MATTER THAT GLOBAL TRADE REFORM ERODES TARIFF PREFERENCES?}

Developing countries are beneficiaries of a number of unilateral preference schemes, notably GSP and more restricted schemes such as the Cotonou Agreement and the Caribbean Basin Initiative. Most recently the EU's Everything But Arms (EBA) initiative for dutyfree, quota-free imports from least-developed countries and the United States African Growth and Opportunities Act in favour of some African countries have provided extended preferences for selected countries. Many developing countries now also participate in an increasing number of sub-regional free-trade agreements and even customs unions. The implication of WTO multilateral negotiations is that MFN tariffs will be cut and the value of these preferences will be eroded. This has led a number of developing countries, especially the LDCs, to take a defensive position on the WTO negotiations, including seeking exemptions or delays for products of greatest interest to them or, compensation for the loss of preferences.

The Generalized System of Preferences was an initiative of Raúl Prebisch, SecretaryGeneral of UNCTAD. Prebisch argued that MFN treatment did not take account of inequality in economic structures and levels of development and, because negotiations were conducted on the basis of reciprocity and the MFN principle, developing countries' exports continued to face high tariffs. Preferences were seen as helping to overcome these disadvantages. Prebisch's proposals were subsequently adopted as a principle at UNCTAD II in New Delhi in 1968, applied initially under a GATT waiver, and ultimately given legal status in the 1971 GATT Decision on Differential and More Favourable
Treatment, Reciprocity and Fuller Participation of Developing Countries (the "Enabling Clause"). The objectives were to increase the export earnings of developing countries, to promote their industrialization and, to accelerate their rates of economic growth.

A recent WTO analysis of the GSP schemes of Canada, the EU, Japan and the United States concludes that "given the high MFN rates that continue to exist in areas of export interest to developing countries, preferences clearly have had some value" (WTO, 2001c). It suggests that the focus on manufactures appeared to have some validity, but that there also appeared to have been a downside through negative effects on agriculture and rural communities in developing countries that could be offset by extending GSP coverage of agricultural products, particularly processed goods.

The WTO study also notes that relatively few countries have benefited from the scheme, a fact that has been used to support graduation and the more selective approach now being applied through the EBA and AGOA. The study states that the effects on development are difficult to determine, and raises the question as to whether developing countries would have been better served by MFN tariff reductions on the kind of goods that they export. In this context, it notes that the unilateral nature of GSP schemes means that benefits can be withdrawn at will and this also creates an element of uncertainty. The study also suggests that some schemes could be better designed, and comments favourably on the relative simplicity and stability of the Japanese scheme. 
The WTO study also draws attention to UNCTAD work on the utilization of preferences (UNCTAD, 1999). This shows that the utilization rate of GSP (the share of GSP qualifying imports entering at the GSP rate) varies in the major schemes from around 40 per cent to 70 per cent for non-LDCs, depending on the market and the year. Utilization by LDCs was as low as 26.7 per cent in the EU in 1997 (attributed to a drop in Bangladesh's utilization of the scheme, because of the complexity of the origin requirements in the textile and clothing sectors). A decline in utilization in the United States from about 70 per cent to around 30 per cent between 1996 and 1997 was attributed to uncertainties regarding the continuation of the scheme after May 1997, and "underscores the importance of the certainty and stability of trade preferences".

African, Caribbean and Pacific (ACP) developing countries that have been granted preferential access to European Union markets for some of their exports under perhaps the most important selective unilateral preference scheme, typically consider themselves privileged, believing that it better enables them to compete in those markets. Not only do they not have to pay the same import duty as other foreign suppliers, but also they receive the EU domestic price, which is higher than the international price to the extent of the protection afforded by the tariff on non-ACP imports.

While the scheme may have provided direct benefits to ACP countries, this has come about to a large extent at the expense of other developing countries that are not in the ACP group. This became very clear in the 1990 s during the dispute-settlement case that was brought to the WTO concerning the EU's banana import regime. One background study showed that for every dollar of benefit that the banana policy brought to producers in ACP countries, the regime harmed non-ACP developing country producers by almost exactly one dollar and, in the process harmed
EU consumers by more than thirteen dollars (Borrell, 1999a). That study concluded that EU citizens could have been thirteen times more effective in helping ACP banana producers without causing any trade damage to non-ACP banana producers at all through direct payments.

The additional production that is encouraged in the ACP countries is no more than a temporary benefit that will disappear under subsequent MFN liberalization. Since at least some of the activities fostered by the scheme will likely be downsized or disappear as the benefits go, to some extent the scheme also represents a welfare loss through the inefficient use of resources and a lost opportunity for investing in other sectors with longer-term comparative advantages. Efforts to learn the skills needed, and the sunk capital invested in that industry rather than in ones in which the country has a natural comparative advantage, would then earn no further rewards. While the scheme has had some short-term advantages, it has also reduced the incentives to improve the policy balance in the ACP countries.

Moreover, the ACP and other nongeneralized discriminatory preference schemes reduce the capacity for developing countries as a group to press for more access to major markets. It does this in two ways: by reducing the number of such countries arguing against protection and, by creating a subset of developing countries supporting the protectionist stance in the EU, the United States and other donors that have sometimes improved preferential access in areas that provide cheap raw materials and other inputs to their own domestic industries. If preferences had not been available, then it seems likely that developing countries would have negotiated much more vigorously in previous GATT rounds for lower tariffs on agricultural and other imports into the EU and other developed country markets. That in turn would have placed greater pressure on these markets to reduce their agricultural protectionism. The 
end result would have been higher international prices for agricultural products that, for developing country producers as a group. This would have offset at least in part, if not wholly, the lower prices received by beneficiaries of current schemes, e.g. ACP countries in the EU market or the privileged sugar exporters to the United States.

A similar set of provisos can be made about the EU's EBA scheme that extends preferences for LDCs. That initiative provides duty-and quota-free access to the EU for exports of all merchandise except arms. Liberal though that proposal sounds, it does not include trade in services (of which the most important for LDCs would be movement of natural persons, that is, freedom for LDC labourers to work in the EU or other high-wage countries). ${ }^{11}$ There are also a number of safeguard provisions included in addition to the EU's normal anti-dumping measures. Furthermore, access to three politically sensitive agricultural markets, bananas, rice and sugar, will be phased in by the EU only gradually over the next eight years (and will be subject to stricter safeguards).

Several empirical studies of the proposal have already appeared. Cernat, Laird, Monge Roffarello and Turrini (2003) show that the modest gains are concentrated in sugar, rice and bananas, with important transfers from ACP countries to non-ACP LDCs (based on GTAP and partial equilibrium modelling). A World Bank study by Ianchovichina, Mattoo and Olarreaga (2001) compares the EU proposal, from the viewpoint of Sub-Saharan Africa (SSA), with recent initiatives of the United States and Japan. Their GTAP modelling results suggest that even the most generous interpretation of the United States Africa Growth and Opportunity Act (which they model as unrestricted access to the United States for all SSA exports) would benefit SSA very little because the United States economy is already very open and, in the products where it is not (e.g. textiles and clothing), SSA countries have little comparative advantage. Likewise they find the Japanese proposal of free access to Japan's market for industrial products helps SSA hardly at all, since the region exports few industrial products. By contrast, the EU scheme, especially if it were to apply to all Quad countries (the EU, the United States, Canada and Japan), would have a sizeable effect on SSA trade and welfare - provided agriculture is included in the deal. Just from EU access alone, SSA exports would be raised by more than US $\$ 0.5$ billion and SSA economic welfare would increase by US $\$ 0.3$ billion per year (a 0.2 per cent boost). This is very similar to a recent estimate by the UNCTAD/Commonwealth Secretariat (2001, Ch. 3).

The estimated benefits are not surprising given that agriculture and food products account for more than half SSA exports. These items are highly protected in the EU and other Quad countries, and little is provided for them in the way of preferential access under the GSP. The results overstate the benefits of the EU proposal however, as this World Bank study assumes all SSA countries (excluding relatively wealthy South Africa and Mauritius), not just the LDCs amongst them, would get duty and quota free access.

Another World Bank study, by Hoekman, Ng and Olarreaga (2001), uses a partial equilibrium approach and looks at the benefit of the EU initiative for LDCs not just in SSA but globally. It finds that trade of LDCs would increase by US $\$ 2.5$ billion per year if all Quad countries provided them duty and

${ }^{11}$ On the potential gains from freeing international trade in unskilled labour services globally, see Winters, Walmsley, Wang and Grynberg (2003). 
quota free access on all merchandise. ${ }^{12}$ However, almost half of that increase would come as a result of trade diversion from other developing countries. The authors suggest this is trivial because it represents less than 0.1 per cent of other developing countries' exports (about US\$1.1 billion). ${ }^{13}$ However, that misses a similar point to the one made above. If the 48 LDCs are given such preferences, they will become advocates for rather than against the continuation of MFN tariff peaks for agriculture and textiles, diminishing considerably the number of WTO members negotiating for their reduction. It may be true that reductions in agricultural and textile tariffs would help LDCs much less than it would help other developing countries, as the study by
Hoekman, Ng and Olarreaga finds but, the gains to consumers in the Quad would be more than sufficient to allow them to increase their aid to LDCs to compensate for the loss of income from preference erosion.

Overall, trade preferences are very much second-best, transitory, discredited, unpredictable and highly conditioned instruments in the face of high protection against the key exports of developing countries. The benefits have been concentrated in relatively few countries, leading to refinements and a proliferation of special schemes that result in setting developing countries against one another, rather than focussing on improved MFN access for their exports in major markets.

${ }^{12}$ This and other estimates of gains from preferential market access provisions need to be discounted to the extent that rules of origin, sanitary and phytosanitary barriers, anti-dumping duties and the like limit the actual trade allowed. For a detailed analysis of these types of restrictions on EU imports from Bangladesh in recent years, see UNCTAD/Commonwealth Secretariat (2001, Ch. 5).

${ }^{13}$ The impact outside the LDC group would be far from trivial for Mauritius, however, since the vast bulk of its exports are quota-restricted sales of clothing and sugar to the EU and the United States. See the discussion in UNCTAD/Commonwealth Secretariat (2001, Ch. 6). 


\section{WOULD FOOD-IMPORTING COUNTRIES LOSE FROM HIGHER INTERNATIONAL FOOD PRICES?}

Some net food-importing developing countries fear agricultural protection cuts by OECD countries will lead to higher international food prices for their imports. Yet even those developing countries need not lose out from farm support cuts abroad. For example, if they are close to self-sufficiency in food without price supports (as are many net food-importing countries in Sub-Saharan Africa), and reform abroad raises the international price of food, they may switch to become sufficiently export-oriented that their net national economic welfare rises. A second possibility is that a developing country's own policies are sufficiently biased against food production that the country is a net importer, despite having a comparative advantage in food. In that case, it has been shown that the international price rise can improve national economic welfare, even if the price change is not sufficient to turn that distorted economy into a net food exporter (Anderson and Tyers, 1993). That comes about because the higher price of food attracts mobile resources away from more-distorted sectors, thereby improving the efficiency of national resource allocation. Because of these two possibilities, the number of poor countries for whom a rise in international food prices might cause some hardship is much smaller than the number that are currently not net exporters of agricultural products. 


\section{WOULD POVERTY AND FOOD INSECURITY INCREASE IN AFRICA BECAUSE OF HIGHER INTERNATIONAL FOOD PRICES?}

The impact of trade liberalization on income distribution and thereby on poverty is not always clear, even though the effects of trade policies on capital owners and workers have been studied by trade theorists for centuries. Applying that theory to the real world turns out to be a complex empirical task (Winters, 2000; McCulloch, Winters and Cirera, 2001; Hoekman et al., 2002). This is because the economy-wide effects depend (a) on the shares of households' income from different productive factors such as labour and land, whose prices will have changed (depending on the size of the changes in relative producer prices, factor substitutability, factor intensities, and factor mobility between sectors), (b) on their expenditure shares on different products (whose consumer prices also will have changed and not necessarily to the same extent as producer prices not least because of marketing margins), and (c) on any changes in net transfers to them (e.g. increased handouts, decreased taxation, more remittances from urban relatives). Those complexities make it difficult to generalize a priori, or even in the face of empirical modelling studies when they report effects of reform just on production, trade, prices and aggregate economic welfare. Even so, some observations are nonetheless worth making about the effects on poverty and food security of reducing agricultural protectionism globally.

Most low-income countries in SubSaharan Africa have not subsidized the producer price of food. In so far as an international food price rise is transmitted domestically, the vast majority of the poor would benefit directly. This is because they are in farm households and are net sellers of food. In other words, they would directly benefit through higher prices and incomes. Moreover, the higher food prices would help generate a supply response in the farm sector. In the case of net food imports, this would contribute towards domestic self-sufficiency or, at least reducing the reliance on imports, while in exporting countries this would also generate higher export earnings.

Even poor landless farm labourers who are net buyers of food could benefit indirectly from agricultural trade liberalization if a rise in the demand for their unskilled labour were to raise employment and, if their wages increased sufficiently to more than offset the rise in food prices. Since the more affluent people in cities would find it relatively easy to pay a little extra for food, the only other major vulnerable group is the under-employed urban poor. But even they need not be worse off because the trade reform would be likely to generate a more-than-offsetting increase in the demand for their (often informal sector) services.

What about the impact of reform on food price variability and other aspects of food security, especially as it affects the poorest households? Contrary to popular belief, trade liberalization is much more likely to reduce than raise food insecurity for the vast majority of the world's poor. Food security means always having access to the minimum supply of basic food necessary for survival. The key to that, in addition to peace and greater efficiency in the functioning of staple food markets, is strengthened purchasing power of the poor. Enhancing food security is mainly about alleviating poverty. The rate of food selfsufficiency is at most only a supplementary indicator, and in developing countries it is 
usually related to the perception that food insecurity rises when the level of food selfsufficiency in basic foods falls much below 100 per cent and the ability to import food is limited to other factors such as exchange rate instability, export earnings and other factors.

Eliminating all agricultural policy distortions in developed countries would raise international prices for agricultural products on average, and reduce their variance by 'thickening' the market, which would stimulate production in non-protected countries. According to one recent study (Diao, Somwaru and Roe, 2001), that would boost the value of agricultural exports of developing countries by 24 per cent while dampening their agricultural imports by just 2 per cent. That suggests food self-sufficiency in many low-income countries would rise. Since a high proportion of the poorest households in developing countries are producers and net sellers of food, they would benefit from such reform. Therefore, in both respects, food security for the vast majority of households in low-income countries should be enhanced on average. Those same households would be helped even further if agricultural price-depressing policies in place domestically were to be removed. The latter reform also boosts self-sufficiency in agricultural products and thereby boosts even further perceived food security in those economies.

The Diao, Somwaru and Roe (2001) study estimates that eliminating developing countries' own agricultural price distortions would boost their farm export value by a further 6 per cent. The households that are net buyers of food in such economies will face higher food prices but, whether they become less food secure depends also on what happens to their earnings (and/or transfers). If they are landless rural poor, their earning prospects will have risen along with the growth in demand for farm labour. As for urban households, the vast majority of them are more affluent than those in rural households and are better able to pay higher market prices for food. This suggests only a small proportion of households in low-income economies would be net food buyers at risk of becoming more food-insecure as a result of rising domestic food prices following agricultural trade reform.

Two points should be stressed. First, eliminating agricultural policy distortions in developed countries would increase the mean and decrease the variance of international prices for agricultural products, which would stimulate production in other countries. That suggests food self-sufficiency would rise in those low-income countries that transmit international prices to their domestic markets. Second, since a high proportion of the poorest households in low-income countries are producers and net sellers of food, they would be key beneficiaries of such reform. Therefore, in both respects food security for the vast majority of households in low-income countries should be enhanced on average. Those same households would be helped even further if they had been subject to pricedepressing domestic policies and these were removed. The latter reform also boosts selfsufficiency in agricultural products and thereby boosts perceived food security even further. 


\section{THE RISK OF RE-INSTRUMENTATION OF AGRICULTURAL PROTECTION}

If reducing agricultural protection/ increasing market access in rich countries is able to contribute to poverty alleviation in developing countries, then that objective will be compromised by efforts to substitute new forms of protection as traditional protective instruments are phased out. The imposition of tariff rate quotas accompanied by very high out-of-quota tariffs, and the administration of quotas so as to ensure less than full usage of them, are two ways in which agricultural protection changes following the Uruguay Round were minimized. As a result, many developing countries are struggling to identify any significant growth in agricultural export earnings resulting from the Uruguay Round Agreement on Agriculture (Mathews, 2002).

There are also at least two ways in which cuts may be minimized following the current WTO negotiations. One is via an expansion of exempt support measures to satisfy so-called non-trade concerns related to the alleged 'multifunctionality' of agriculture, even though those concerns can readily be met much more directly and hence in less tradedistorting ways than is being proposed (Anderson, 2000; Paarlberg, Bredahl and Lee, 2002). While the proposal originated in the richest, most-protective economies, it is now being embraced by farmer groups in numerous developing countries as well. More than twenty such countries' farm groups plus the EU met in Geneva during the period 23-25 October 2002 and signed a declaration calling on WTO members to acknowledge that "agriculture cannot be treated in the same way as industrial sectors" because farming "fulfils a multitude of functions ..."

The other is via the adoption of stricter standards that then act as technical barriers to trade. Quarantine measures are an obvious case in point. They often add relatively large cost burdens to exporters from poorer countries because those countries do not have the same capability as developed countries to meet high standards (Wilson, 2002). Studies are now emerging of SPS measures of OECD countries that are already significantly hindering the exports of developing countries (see, for example, Mathews, 2002, etc). Another is the increasing use of geographical indications and traditional expressions aimed at differentiating rich-country products, which effectively reduces the demand for substitute products from other countries. A less-obvious possibility is the restriction of imports of food products containing genetically modified organisms (GMOs). The direct short-term effects of a ban on GMOs could help exports from developing countries that choose not to adopt GMOs even though it harms those who have already adopted GMOs (Nielsen and Anderson, 2001; Anderson and Yao, 2003). In the longer term, such a ban would likely have a negative effect on investment in agricultural biotechnologies that could lower food prices and/or raise the nutritional attributes of foods available in developing countries. 


\section{CONCLUSIONS AND POLICY IMPLICATIONS}

Low-income countries in Sub-Saharan Africa cannot be indifferent to the current WTO multilateral trade negotiations. They have a strong vested interest in working together to push simultaneously for the freeing of trade in both farm and textile products. ${ }^{14}$ Achieving that end may also require some opening up of developing economies themselves, but computations show that in the longer term this would benefit rather than hurt the poor in their own economies, provided that the pace and sequencing is properly handled and sufficient resources are provided by the donor community to cushion the costs and facilitate the implementation of adjustment programmes. Such a change in policies would also be politically easier the more that developed countries reform their farm policies, thereby raising the mean and lowering the variance of international food prices.

However, there could be important short-term adjustment costs, and negative effects are likely to be concentrated in the industrial sector. There is a view that promotion of industrial development has certain social benefits. On the other hand, a number of studies show that industrial protection may have had an important antiagricultural bias in some countries and hence has fallen heavily on the rural poor. In the longer term, this apparent sectoral policy dilemma can only be solved through an increase in investment sufficient to promote broader-based economic growth and employment.
In some African countries at least, preparedness to adapt their own policies would be greater if mechanisms were introduced that increased perceived food security. If a society would feel too food-insecure under laissez faire, what needs to be determined is a sense of (a) its willingness to pay for more security by various means, and (b) the costs of those insurance measures. One such measure involves encouraging the holding of food stocks above those that would be commercially viable - a public good that is explicitly allowed for in Annex 2 of the WTO's Agreement on Agriculture. The optimal level of encouragement is that which boosts stocks so that the marginal social benefit in terms of food security equals the marginal social cost of that intervention. However, costs are not trivial. Storage and interest costs and the costs of spoilage and quality deterioration can amount to more than 20 per cent a year. The cost part of the calculation also would need to include the risk of government failure if stocks were to be managed by an inefficient (or corrupt) public agency.

If greater domestic production capability were considered by society to be one of the desirable means of boosting food security (because of a perception that food import dependence is too unreliable), there may be less costly ways of achieving that, for example through production support (provided there is sufficient latitude under WTO rules), rather than via protection from food imports. Even more effective could be improvements in land

14 Within agriculture, developing countries' interests in Doha agenda items align closely with those of the Cairns Group of non-subsidizing agricultural-exporting countries (Bjornskov and Lind, 2002). See Cairns Group (2002) for its proposal on market access in the Doha Round. 
tenure and more investment in the stocks of primary factors used in food production: agricultural research, ${ }^{15}$ rural human capital, and rural infrastructure (Otsuka, 2002). There are already a number of international efforts and national programmes in this area, but further support would provide an especially high payoff in situations where, as in so many countries, there has been gross underinvestment in these activities in the past. Simultaneously, production could be boosted in many low-income countries simply by better clarifying and enforcing land rights, since they are a key source of collateral for securing loans for productive investments by farm households.

Where targeted programmes to boost the earning capacity of the poverty-stricken (e.g. via basic education/training) are still not enough to boost their food security in the short term, targeted consumer subsidies to provide that core group with food staples would be much less costly than general subsidies to all food consumers via price-depressing agricultural policies. Food aid that is targeted to just that group could be readily provided by the international community without depressing very much the prices received by farmers in recipient countries. ${ }^{16}$ Greater technical and economic cooperation in the areas of agricultural research, rural education and health, and rural infrastructure may be important co-requisites of trade policy reform if developing countries are to be convinced that they would gain unequivocally from the current WTO negotiations.

${ }^{15}$ For recent reviews of the substantial contribution that a further boost to agricultural research could do for poverty alleviation in low-income countries, see Hazell and Haddad (2001) and Runge et al. (2003).

${ }^{16}$ If such subsidies are only paid in the towns and cities however, this increases the risk of excessive, socially costly migration out of agriculture of the sort analysed by Harris and Todaro (1970). 


\section{REFERENCES}

Anderson, K. (2000), 'Agriculture's Multifunctionality and the WTO', Australian Journal of Agricultural and Resource Economics 44(3): 475-94, September.

Anderson, K. (2002), 'Economy-wide Dimensions of Trade Policy Reform', Ch. 2 in Development, Trade and the WTO: A Handbook, edited by B. Hoekman, A. Matoo and P. English, Washington, D.C.: The World Bank.

Anderson, K., B. Dimaranan, T. Hertel and W. Martin (1997a), 'Asia-Pacific Food Markets and Trade in 2005: A Global, Economy-Wide Perspective', Australian Journal of Agricultural and Resource Economics 41(1): 19-44.

Anderson, K., B. Dimaranan, T. Hertel and W. Martin (1997b), 'Economic Growth and Policy Reforms in the APEC Region: Trade and Welfare Implications by 2005', Asia-Pacific Economic Review 3(1): 1-18, April.

Anderson, K., B. Dimaranan, J. Francois, T. Hertel, B. Hoekman and W. Martin (2001), 'The Cost of Rich (and Poor) Country Protection to Developing Countries', Journal of African Economies 10(3): 227-57.

Anderson, K. and B. Hoekman (2000), "Developing Country Agriculture and the New Trade Agenda”, Economic Development and Cultural Change 49(1): 171-80, October.

Anderson, K. and A. Strutt (1999), 'Impact of East Asia's Growth Interruption and Policy Responses: The Case of Indonesia', Asian Economic Journal 13(2): 205-18, June.

Anderson, K. and R. Tyers (1993), 'More on Welfare Gains to Developing Countries from Liberalizing World Food Trade', Journal of Agricultural Economics 44(2): 189-204, May.

Anderson, K. and S. Yao (2003), 'How Can South Asia and Sub-Saharan Africa Gain From the Next WTO Round?' Journal of Economic Integration 18(3): 466-81, September.

Anderson, K. and S. Yao (2003), "China, GMOs and World Trade in Agricultural and Textile Products”, Pacific Economic Review 8(2): 157-69, June.

Berg, A. and A.O. Krueger (2002), 'Trade, Growth and Poverty', paper presented at the Annual World Bank Conference on Development Economics, Washington, D.C.

Bjornskov, C. and K.M. Lind (2002), 'Where do Developing Countries Go After Doha? Journal of World Trade 36(3): 543-62. 
Borrell, B. (1999a), 'Bananas: Straightening Out Bent Ideas on Trade as Aid', Paper presented at the World Bank/WTO Conference on Agriculture and the New Trade Agenda from a Development Perspective, Geneva, 1-2 October.

Borrell, B. (1999b), 'Sugar: The Taste Test of Trade Liberalization', Paper presented at the World Bank/WTO Conference on Agriculture and the New Trade Agenda from a Development Perspective, Geneva, 1-2 October.

Bouguignon F. and C. Morrisson (2002), 'Inequality Among World Citizens: 1820-1992', American Economic Review 92(4): 727-44, September.

Brown, L.R. (1995), Who Will Feed China? Wake-up Call for a Small Planet, Washington, D.C.: Worldwatch Institute.

Brown, D. K., A. V. Deardorff and R. M. Stern (2001). 'CGE Modelling and Analysis of Multilateral and Regional Negotiation Options', Research Seminar in International Economics, Discussion Paper No. 468.

Cairns Group (2002), 'Negotiating Proposal on Market Access', submission to the Committee on Agriculture Special Session, JOB(02)/1126, WTO, Geneva, September.

Cernat, L., L. Monge-Roffarello, S. Laird and A. Turrini (2003), “The EU's Everything but Arms Initiative and the Least-developed Countries", UNU WIDER Discussion Paper No. 2003/ 47, Helsinki.

Chen, S. and M. Ravallion (2001), 'How Did the World's Poorest Fare in the 1990s?' mimeo, Development Research Group, World Bank. Washington, D.C.

Chen, S. and M. Ravallion (2004), 'Household Welfare Impacts of China's Accession to the WTO', in China and the World Economy: Policy and Poverty after China's Accession to the WTO, edited by D. Bhattasali, S. Li and W. Martin, London and New York: Oxford University Press (forthcoming).

Corden, W.M. (1997), Trade Policy and Economic Welfare (revised edition), Oxford: Clarendon Press.

Collier, P. and D. Dollar (2002), Globalization, Growth, and Poverty, New York: Oxford University Press for the World Bank.

Diao, X, A. Somwaru and T. Roe (2001), 'A Global Analysis of Agricultural Reform in WTO Member Countries', Background paper for a USDA project on Agricultural Policy Reform in the WTO: The Road Ahead, ERS-E01-001, Washington, D.C.: US Department of Agriculture.

Dollar, D. and A. Kraay (2002), 'Growth is Good for the Poor', Journal of Economic Growth 7(3): 195-225, September. 
Findlay, C.C. and A. Warren (eds.) (2000), Impediments to Trade in Services: Measurement and Policy Implications, London: Routledge.

Francois, J, (2001), The Next WTO Round: North-South Stakes in New Market Access Negotiations, Adelaide: Centre for International Economic Studies, and Rotterdam: Tinbergen Institute.

Francois, J. and A. Strutt (1999), 'Post-Uruguay Round Tariff Vectors for GTAP Version 4', Erasmus University manuscript, Rotterdam.

Francois, J.F. and I. Wooten (2001), 'Trade in International Transport Services: The Role of Competition', Review of International Economics 9(2): 249-61, May.

Hagen, R.J., O. Maestad and A. Michelsen (2001), 'Economic Impact on the Least Developed Countries of the Elimination of Import Tariffs on Their Products', Bergen: Norwegian School of Economics and Business Administration, May.

Harris, J.R. and M.P. Todaro (1970), 'Migration, Unemployment and Development: A Two-Sector Analysis', American Economic Review 60(1): 126-42, March.

Harrison, W. J. and K. R. Pearson (1996), 'Computing Solutions for Large General Equilibrium Models Using GEMPACK’, Computational Economics 9: 83-172.

Hazell, P. and L. Haddad (2001), 'Agricultural Research and Poverty Reduction', IFPRI Discussion Paper 34, Washington, D.C.: International Food Policy Research Institute, August.

Hertel, T.W. (ed.) (1997), Global Trade Analysis: Modeling and Applications, Cambridge and New York: Cambridge University Press.

Hertel, T., K. Anderson, J. Francois, B. Hoekman and W. Martin (2004), 'Agriculture and Nonagricultural Liberalization in the Millennium Round', Ch. 11 in Issues, Interests and Options in the New WTO Trade Round, edited by M.D. Ingco and L.A. Winters, Cambridge and New York: Cambridge University Press (forthcoming).

Hoekman, B. (1996), 'Assessing the General Agreement on Trade in Services', Ch. 4 in The Uruguay Round and the Developing Countries, edited by W. Martin and L.A. Winters, Cambridge and New York: Cambridge University Press.

Hoekman, B., C. Michalopoulos, M. Schiff and D. Tarr (2001), 'Trade Policy Reform and Poverty Alleviation', World Bank Trade Working Paper \# 2773, Washington, D.C., December.

Hoekman, B., F. Ng and M. Olarreaga (2002), 'Eliminating Excess Tariffs on Exports of Least Developed Countries', World Bank Economic Review 16: 1-21, January.

Ianchovichina, E., A. Mattoo and M. Olarreaga (2001), 'Unrestricted Market Access for SubSaharan Africa: How Much is it Worth and Who Pays?' CEPR Discussion Paper No. 2820, London: Centre for Economic Policy Research, June. 
Jensen, H.T., S. Robinson and F. Tarp (2002), 'General Equilibrium Measures of Agricultural Policy Bias in Fifteen Developing Countries', TMD Discussion Paper No. 102, IFPRI, Washington DC, October.

Krueger, A., M. Schiff and A. Valdez (1988), "Agricultural Incentives in Developing Countries: Measuring the Effects of Sectoral and Economy-wide Policies", World Bank Economic Review 2(7), September.

Laird, S. (1997), "Quantifying Commercial Policies”, in J.F. Francois and K. Reinert (eds.), Applied Trade Policy Modelling: A Handbook, Cambridge and New York: Cambridge University Press.

Martin, W. (2001), 'Trade Policies, Developing Countries, and Globalization', in Globalization, Policy Research Report, Washington, D.C.: The World Bank.

Martin, W. and L.A. Winters (eds.) (1996), The Uruguay Round and the Developing Countries, Cambridge and New York: Cambridge University Press.

Mathews, A. (2002), 'Developing Country Experience With the Implementation of the Uruguay Round Agreement on Agriculture: Synthesis of the Findings of 23 Country Case Studies', FAO Geneva Symposium on Implementing the WTO's URAA, 2 October.

McCulloch, N., L.A. Winters and X. Cirera (2001), Trade Liberalization and Poverty: A Handbook, London: Centre for Economic Policy Research.

McDougall, R.A., A. Elbehri and T.P. Truong (1998) (eds.) Global Trade, Assistance, and Protection: The GTAP 4 Data Base. Center for Global Trade Analysis, Purdue University, West Lafayette.

Nielsen, C. and K. Anderson (2001), 'Global Market Effects of European Responses to Genetically Modified Organisms', Weltwertschaftliches Archiv 137(2): 320-46, June.

Otsuka, K. (2002), 'Poverty Reduction Issues: Village Economy Perspective', Asian Development Review 19(1): 98-116.

Paarlberg, P.L., M. Bredahl and J.G. Lee (2002), 'Multifunctionality and Agricultural Trade Negotiations', Review of Agricultural Economics 24(2): 322-35, Fall.

Rodrik, D. (1999): The New Global Economy and Developing Countries: Making Openess Work, Washington, DC: Overseas Development Council, Policy Essay 24.

Runge, C.F., B. Senauer, P.G. Pardey and M.W. Rosegrant (2003), Ending Hunger in Our Lifetime: Food Security and Globalization, Baltimore: Johns Hopkins University Press.

Sala-i-Martin, X. (2002), 'The World Distribution of Income (Estimated from Individual Country Distributions)', NBER Working Paper 8933, Cambridge MA, May. 
UNCTAD (1999), "Quantifying the benefits obtained by developing countries from the Generalized System of Preferences", Note by the UNCTAD secretariat (UNCTAD/ITCD/TSB/Misc.52 of 7 October 1999).

UNCTAD/Commonwealth Secretariat (2001), Duty and Quota Free Market Access for LDCs: An Analysis of Quad Initiatives, Geneva: UNCTAD and London: Commonwealth Secretariat.

UNCTAD (2003), "Back to Basics - Market access issues in the Doha Agenda", United Nations publication, Sales No. E.03.II.D.4), Geneva.

Winters, L.A., T. Walmsley, Z.K. Wang and R. Grynberg (2003), 'Liberalizing Temporary Movement of Natural Persons: An Agenda for the Development Round', The World Economy 26(8): 1137-61, August.

Wilson, J.S. (2002), 'Standards, Trade and Development: What is Known and What Do We Need to Know?' Paper presented at the Roundtable on Informing the Doha Process: New Research for Developing Countries, Cairo, 20-21 May.

Winters, L.A. (2000), 'Trade, Trade Policy and Poverty: What Are the Links?' Background paper for the World Bank's World Development Report 2000/01, January.

Winters, L.A., N. McCulloch and A, McKay (2002), 'Trade Liberalization and Poverty: Empirical Evidence', mimeo, University of Sussex, September.

World Bank (2002), Global Economic Prospects and the Developing Countries: Making World Trade for the World's Poor, Washington, D.C.: The World Bank.

World Bank (2003), Global Economic Prospects 2004: Realizing the Development Promise of the Doha Agenda, Washington, D.C.: The World Bank, September.

WTO (2001a), Market Access: Unfinished Business: Post-Uruguay Round Inventory and Issues, Special Study No. 6, Geneva: World Trade Organization.

WTO (2001b), Doha WTO Ministerial 2001: Ministerial Declaration, WT/MIN(01)/DEC/1, Geneva: World Trade Organization, 14 November.

WTO (2001c), The Generalized System of Preferences: A preliminary analysis of the GSP schemes in the Quad, Note by the Secretariat (WT/COMTD/W/93, 5 October 2001). 


\section{POLICY ISSUES IN INTERNATIONAL TRADE AND COMMODITIES}

No. 1 Erich Supper, Is there effectively a level playing field for developing country exports?, 2001, 138 p. Sales No. E.00.II.D.22.

No. 2 Arvind Panagariya, E-commerce, WTO and developing countries, 2000, 24 p. Sales No. E.00.II.D.23.

No. 3 Joseph Francois, Assessing the results of general equilibrium studies of multilateral trade negotiations, 2000, 26 p. Sales No. E.00.II.D.24.

No. 4 John Whalley, What can the developing countries infer from the Uruguay Round models for future negotiations?, 2000, 29 p. Sales No. E.00.II.D.25.

No. 5 Susan Teltscher, Tariffs, taxes and electronic commerce: Revenue implications for developing countries, 2000,57 p. Sales No. E.00.II.D.36.

No. 6 Bijit Bora, Peter J. Lloyd, Mari Pangestu, Industrial policy and the WTO, 2000, 47 p. Sales No. E.00.II.D.26.

No. 7 Emilio J. Medina-Smith, Is the export-led growth hypothesis valid for developing countries? A case study of Costa Rica, 2001, 49 p. Sales No. E.01.II.D.8.

No. 8 Christopher Findlay, Service sector reform and development strategies: Issues and research priorities, 2001, 24 p. Sales No. E.01.II.D.7.

No. 9 Inge Nora Neufeld, Anti-dumping and countervailing procedures - Use or abuse? Implications for developing countries, 2001, 33 p. Sales No. E.01.II.D.6.

No. 10 Robert Scollay, Regional trade agreements and developing countries: The case of the Pacific Islands' proposed free trade agreement, 2001, 45 p. Sales No. E.01.II.D.16.

No. 11 Robert Scollay and John Gilbert, An integrated approach to agricultural trade and development issues: Exploring the welfare and distribution issues, 2001, 43 p. Sales No. E.01.II.D.15.

No. 12 Marc Bacchetta and Bijit Bora, Post-Uruguay round market access barriers for industrial products, 2001, 50 p. Sales No. E.01.II.D.23.

No. 13 Bijit Bora and Inge Nora Neufeld, Tariffs and the East Asian financial crisis, 2001, 30 p. Sales No. E.01.II.D.27. 
No. 14 Bijit Bora, Lucian Cernat, Alessandro Turrini, Duty and Quota-Free Access for LDCs: Further Evidence from CGE Modelling, 2002, 130 p. Sales No. E.01.II.D.22.

No. 15 Bijit Bora, John Gilbert, Robert Scollay, Assessing regional trading arrangements in the Asia-Pacific, 2001, 29 p. Sales No. E.01.II.D.21.

No. 16 Lucian Cernat, Assessing regional trade arrangements: Are South-South RTAs more trade diverting?, 2001, 24 p. Sales No. E.01.II.D.32.

No. 17 Bijit Bora, Trade related investment measures and the WTO: 1995-2001, 2002.

No. 18 Bijit Bora, Aki Kuwahara, Sam Laird, Quantification of non-tariff measures, 2002, 42 p. Sales No. E.02.II.D.8.

No. 19 Greg McGuire, Trade in services - Market access opportunities and the benefits of liberalization for developing economies, 2002, 45 p. Sales No. E.02.II.D.9.

No. 20 Alessandro Turrini, International trade and labour market performance: major findings and open questions, 2002, 30 p. Sales No. E.02.II.D.10.

No. 21 Lucian Cernat, Assessing south-south regional integration: same issues, many metrics, 2003, 32 p. Sales No. E.02.II.D.11.

No. 22 Kym Anderson, Agriculture, trade reform and poverty reduction: implications for Sub-Saharan Africa, 2004, 30 p. Sales No. E.04.II.D.5.

United Nations publications may be obtained from bookstores and distributors throughout the world. Please consult your bookstore or write to:

\section{United Nations Publications}

All orders from North America, Latin America, the Caribbean and Asia and the Pacific should be sent to:

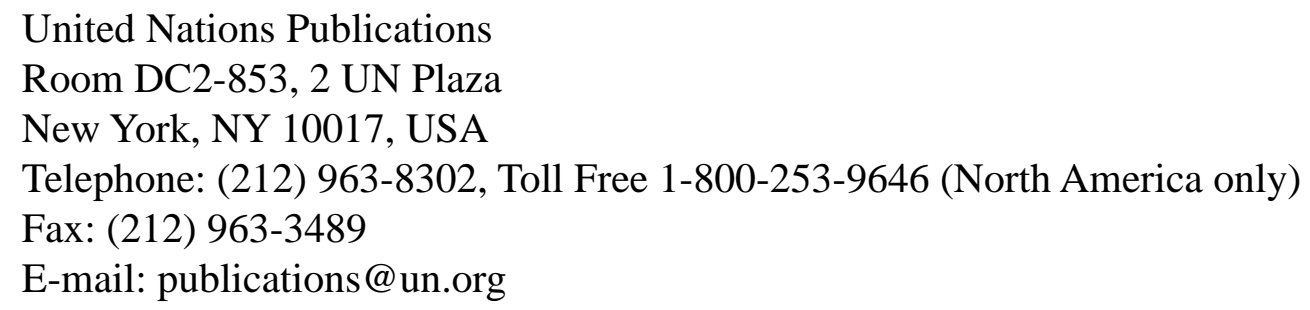

Customers in Europe, Africa and the Middle East should send their orders to:

Section des Ventes et Commercialisation

Bureau E-4, CH-1211

Geneva 10, Switzerland

Telephone: 41 (22) 917-2613/2614

Fax: 41 (22) 917-0027

E-mail: unpubli@unog.ch 


\title{
QUESTIONNAIRE
}

\section{UNCTAD Study Series on \\ POLICY ISSUES IN INTERNATIONAL TRADE AND COMMODITIES}

(Study series no. 22: Agriculture, Trade Reform and Poverty Reduction:

Implications for Sub-Saharan Africa)

\section{Readership Survey}

Since 1999, the Trade Analysis Branch of the Division on International Trade in Goods and Services, and Commodities of UNCTAD has been carrying out policy-oriented analytical work aimed at improving the understanding of current and emerging issues in international trade of concern to developing countries. In order to improve the quality of the work of the Branch, it would be useful to receive the views of readers on this and other similar publications. It would therefore be greatly appreciated if you could complete the following questionnaire and return to:

\author{
Jenifer Tacardon-Mercado \\ TAB/DITC, Rm. E-8076 \\ United Nations Conference on Trade and Development \\ Palais des Nations \\ CH-1211 Geneva 10, Switzerland
}

1. Name and address of respondent (optional):

2. Which of the following describes your area of work?

Government

Private enterprise institution

International organization

Not-for-profit organization

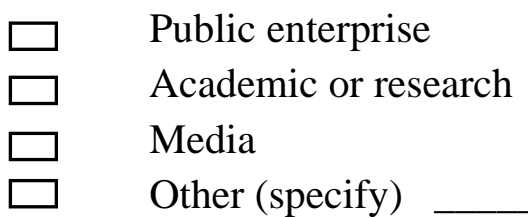

Other (specify)

3. In which country do you work?

4. Did you find this publication $\quad \square$ Very useful $\quad \square$ Of some use $\square$ Little use to your work?

5. What is your assessment of the contents of this publication?

$\square$ Excellent $\square$ Good $\square$ Adequate $\quad \square$ Poor

6. Other comments: 